\title{
Reviewing the Impact of Vehicular Pollution on Road-Side Plants-Future Perspectives
}

\author{
Manikandan Muthu ${ }^{1}$, Judy Gopal ${ }^{1}$ (D), Doo-Hwan Kim ${ }^{2}$ and Iyyakkannu Sivanesan ${ }^{2, *(D)}$ \\ 1 Laboratory of Neo Natural Farming, Chunnampet, Tamil Nadu 603 401, India; \\ bhagatmani@gmail.com (M.M.); jejudy777@gmail.com (J.G.) \\ 2 Department of Bioresources and Food Science, Institute of Natural Science and Agriculture, \\ Konkuk University, 1 Hwayang-dong, Gwangjin-gu, Seoul 05029, Korea; kimdh@konkuk.ac.kr \\ * Correspondence: isivanesan@gmail.com; Tel.: +82-24500574; Fax: +82-24503310
}

check for updates

Citation: Muthu, M.; Gopal, J.;

Kim, D.-H.; Sivanesan, I. Reviewing the Impact of Vehicular Pollution on Road-Side Plants-Future

Perspectives. Sustainability 2021, 13,

5114. https://doi.org/10.3390/

su13095114

Academic Editor: Silvia Fiore

Received: 10 April 2021

Accepted: 26 April 2021

Published: 3 May 2021

Publisher's Note: MDPI stays neutral with regard to jurisdictional claims in published maps and institutional affiliations.

Copyright: (C) 2021 by the authors. Licensee MDPI, Basel, Switzerland. This article is an open access article distributed under the terms and conditions of the Creative Commons Attribution (CC BY) license (https:/ / creativecommons.org/licenses/by/ $4.0 /)$.

\begin{abstract}
With population explosion, automobiles have also exploded and so has pollution due to vehicular emissions. Road-side plants and highway vegetation are the first targets of these vehicular emissions. This review briefly presents a snapshot of how vehicular emission can affect plants. On the contrary, the positive perspective of how road-side plants may be able to affect and influence the harmful effects of vehicular emissions has also been discussed. Ways and means by which plants can become potential bio indicators of air pollution have also been speculated. The fact that the nanocarbon particulate aspect of automobile pollutants and their interactions with road-side plants and more so on road-side agricultural crops, has not been appropriately investigated has been raised as a key concern. The need to arrive at mitigation methods to identify permanent solutions to these rising concerns has been highlighted.
\end{abstract}

Keywords: automobile emission; highway/roadside plants; carbon nanoparticles; dust; pollution; air pollution

\section{Introduction}

The recent decades have seen a gradual increase in the global population from 7.4 billion in 2016 to 7.7 billion in 2019, 7.8 billion in 2020 to 7.9 billion in 2021. The world population is projected to reach 9.9 billion by 2050 . With urbanization, industrialization, and various commercial activities rising to meet the demands of this exponentially increasing population, transportation needs have increased too. The use of private vehicles has also stealthily increased because the public transport systems are inadequate. Two-wheelers (motorcycles, scooters), being an easy and relatively cheaper means of commutation compared to four wheelers, have increased, mostly in developing countries [1]. Globally, 5 decades ago about 53 million automobiles were approximated, this has boomed to 500 million in 2000 and every year about 19 million vehicles are added [2]. It is an understandable increase in two wheelers, since they are an economic mode of transport. Four wheelers are also anticipated to double up in the near future.

Automobile-based air pollution amounts to 60 to $70 \%$, with harmful emissions such as carbon monoxide, hydrocarbons, nitrogen oxide, volatile organic compounds, fine particles, carbon nanomaterial, and lead being released into the atmosphere (Figure 1). Old age, poor performance, and inadequate maintenance of vehicles enhance these emissions. Narrow roads, frequent traffic jams, poor geometrics, and congestion aggravate this further, affecting human health and the environment. Two and three wheelers emissions are about twice the amount emitted by all other sources. Researchers have reported 800,000 deaths annually as a result of urban air pollutants [3]. 


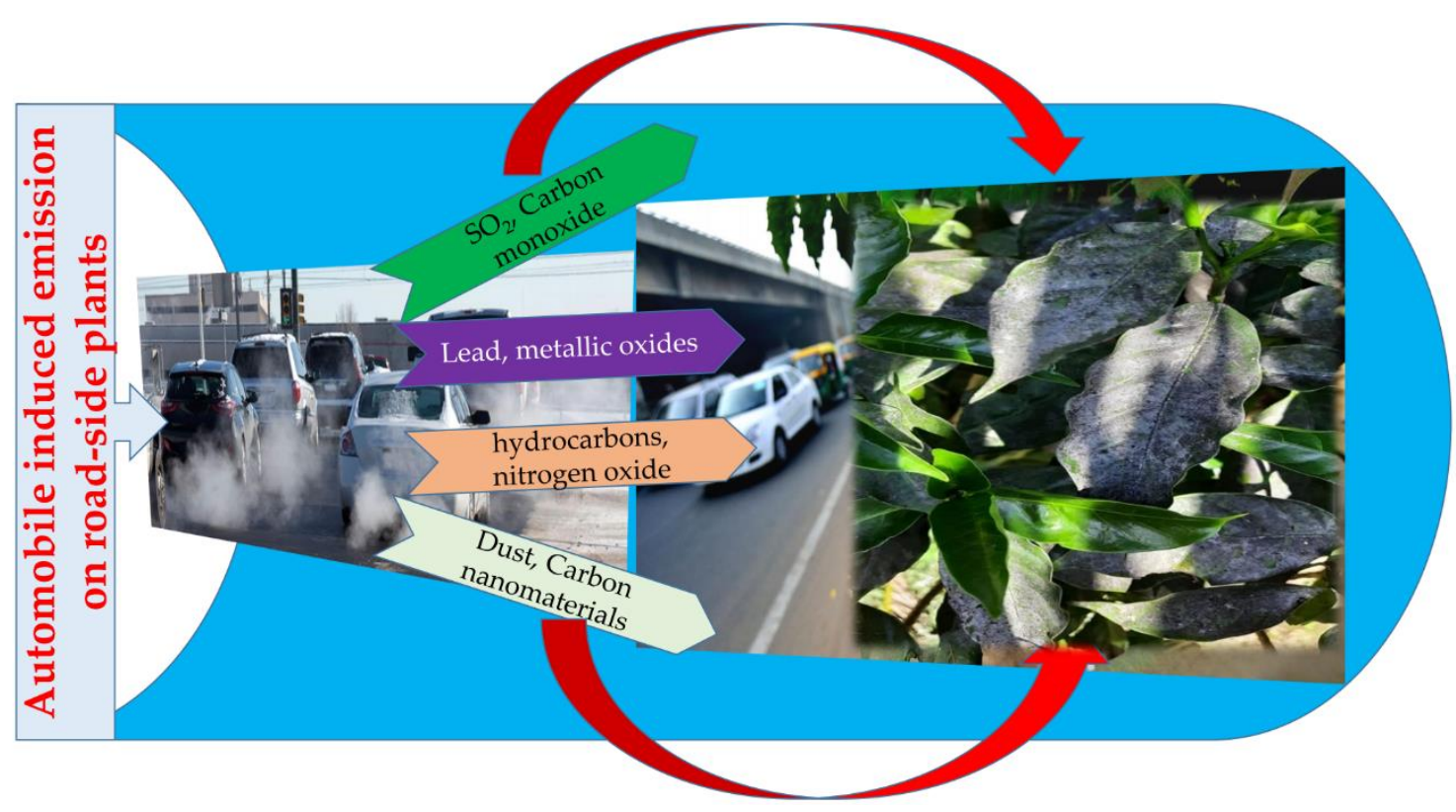

Figure 1. Various vehicular pollutants to which road-side plants are vulnerable.

Treshow [4] defined air pollutants as "aerial substances that have adverse effects on plants, animals or materials". Air pollutants consist of particulate and gaseous pollutants. Particulate pollutants may be solid or liquid particles that may be large or small. Larger particles (sand grains, water droplets) quickly deposit, while smaller dust stays in the air for longer durations of time. Based upon their chemical nature, particulate pollutants could be either inorganic particulate matter (I.P.M) or organic particulate matter (O.P.M) [5].

This review presents the impact of automobile-based effects on highway/roadside plants. The existing knowledge on the physiological and morphological changes these highway plants are subjected to, has been briefly discussed. The positive influence highway plants have on reducing automobile-based effects has also been discussed. The practical implementation of this acquired knowledge has been speculated and discussed.

\section{Impact of Vehicular Emissions on Highway Plants}

Plants are susceptible to air pollutants, deposition of pollutant particulates on soil indirectly affects plant growth. Automobile-based pollutants deposit on leaves, blocking the stomata and eventually affecting transpiration. These depositions obstruct $\mathrm{CO}_{2}$ absorption and eventually decrease photosynthesis and affect the growth of plants and their productivity. Agarawal and Agrawal [6] have elaborately evaluated pollution in Dhaka city and discussed its associated health impacts. They have also confirmed that the high density of motor vehicles to be the reason for high pollution levels. This automobile linked pollution is expected to worsen with further increase in economic growth and industrialization. Rawat [7] studied the negative effects of automobile pollution on roadside plants on Mussoorie Road. Bakshi [8] investigated roadside air quality of Jammu city. They reported higher levels of suspended particulate matter (SPM) owing to heavy automobile traffic. Raina and Sharma [9] studied the impacts of automobile pollutants on leaf anatomy, morphology, and chlorophyll of Syzgium cumini L. and reported a decrease in all parameters. Raina et al. [10] studied the influence of exhaust on trees growing along the road sides, they found that Albizzia lebbek was more adaptive to polluted environments. Nithamathi and Indira [11] reported damages on flowers and seeds of Ceasalpinia sepiaria L. in Tuticorin city. Many researchers around the world have explored the negative effects of air pollutants on plants [12-29]. Other workers have explored the impacts of air pollutants on the external morphology and anatomy of plants [30-40]. However, negative impacts of vehicular emission on plants are rather few and limited. 
Incomplete combustion of petrol emanates nitrous oxide, sulfur dioxide, lead, carbon monoxides, and particulate matter that damage the foliage of plants [41]. The growth and morphological characteristics of plants can be affected by exposure to heavy metals released from automobile exhausts. Pyatt [42] and Feder [43] observed foliar injury, chlorosis on leaves and other parts of plants, and morphological effects on younger leaves and stunted growth as a result of exposure to air pollutants. Figure 2 portrays the overall damages inflicted by vehicular emissions on road-side plants.

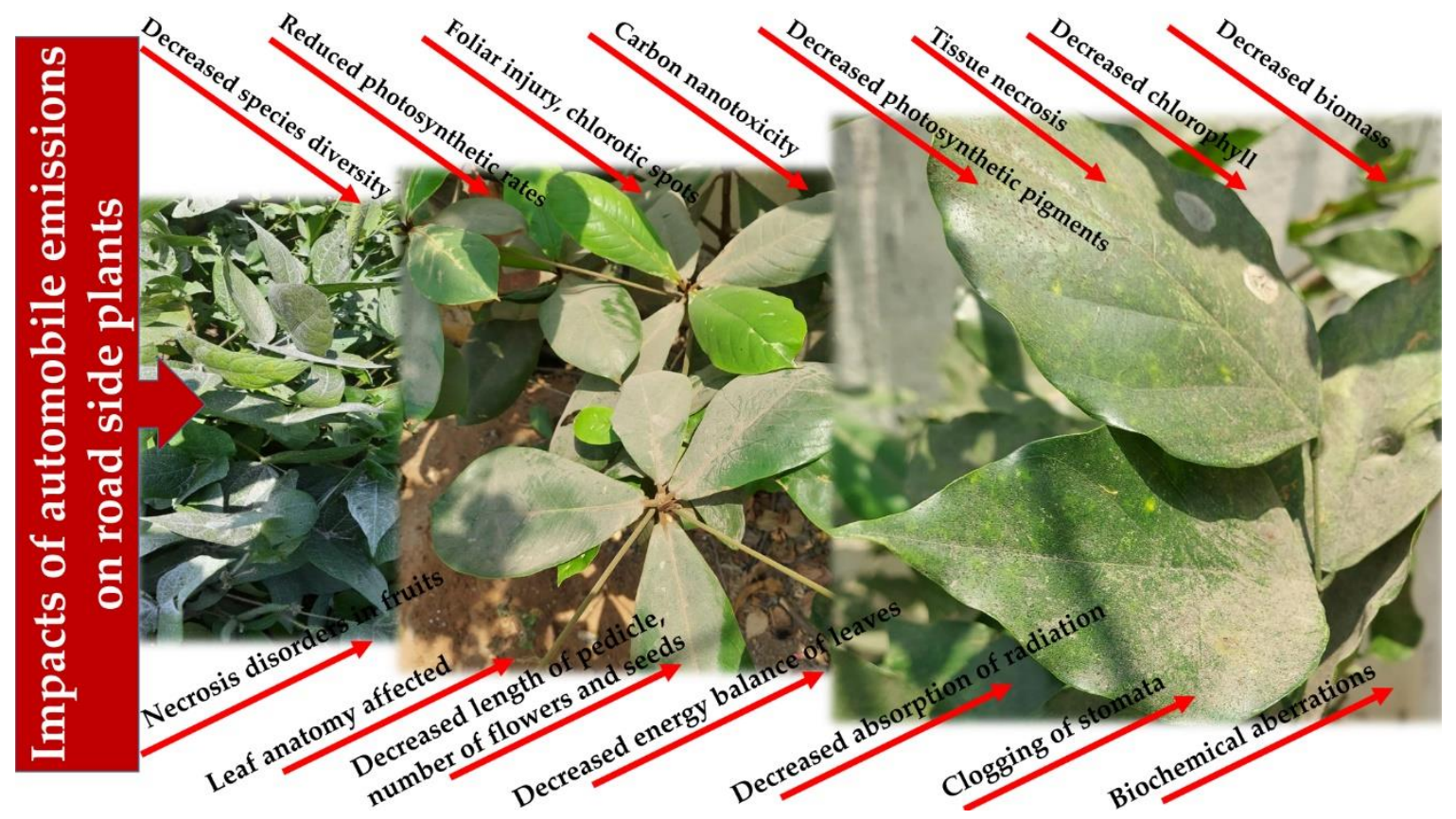

Figure 2. Schematic showing the various ways road-side plants are impacted by vehicular emissions.

Other authors [44] reported that gaseous pollutants are absorbed by leaves, while the particulate ones are absorbed on the outer surfaces of the plants and are not that injurious. Furukawa et al. [45] correlated injury to the magnitude of $\mathrm{SO}_{2}$ absorbed. Plants sensitive to $\mathrm{SO}_{2}$, absorbed higher quantities of gas than those that are resistant. Treshow [4] found that the interference of pollutants affects the green coloration of leaves and brought about death of plant tissues. Bhatti and Iqbal [37] studied the impact of automobile exhausts on roadside trees in Karachi. In all the exposed plant species, foliage productivity was highly reduced in heavily polluted sites. Guaiacum officinale was most affected and Azardirachta indica was least affected and therefore $A$. indica has been proposed for road-side plantation.

Dust is yet another cause of concern. Dust from automobiles evolves from the exhausts as well as due to vehicular movement on roads. Dust is not just a concern for highway plants, as a matter of fact, every road-side plant is vulnerable to dust. Recently, there is a lot of concern over particle pollution. Automobile emission is one of the predominant sources of such particle pollution. These particles have been named as PM2.5 and PM10 which are very dangerous. These, not just settle on the surface, but move into the system (humans and plants). PM2.5 refers to the atmospheric particulate matter that has a diameter of less than 2.5 micrometers, while PM10 are the particles with a diameter of 10 micrometers. These particles have been studied elaborately with respect to their interactions with the human body, nothing much has been explored with respect to plants.

Vora and Bhatnagar [46] observed high dust accumulation in areas exposed to dense automobile exhausts. Dust on road-side vegetation is usually due to automobile, vehicular exhaust, thermal and coal power plant, and cement and brick kilns [47-62]. Dust-fall having $\mathrm{pH}$ more than 9 can cause injury to the leaves of plants $[63,64]$. Deposition of dust on leaf surfaces can affect its optical properties, especially leaf surface reflectance in the visible and near infrared region $[65,66]$. Sharifi et al. [67] confirmed that deposition of $40 \mathrm{~g} \mathrm{~m}^{-2}$ 
dust can lead to a $2-3{ }^{\circ} \mathrm{C}$ increase in leaf temperature. The species having sunken stomata are least affected. Dust on leaves also affects photosynthesis and growth $[67,68]$. Fine dust particles clog stomata [69,70], reduce photosynthesis [71], elevate leaf temperature [72,73], and enhance transpiration $[74,75]$.

Hussain et al. [76] studied some road-side trees of Peshawar city. They confirmed that the leaf area and chlorophyll contents of all the polluted plants were reduced. Another study [77] on the influence of road dust on the absorption of radiation and energy balance of leaves, confirmed that dusty Hedera helix leaves near the pavement absorbed 30\% more radiation and Rhododendrom catawbinse dust covered leaves absorbed $16 \%$ more radiation. Chlorophyll ' $a$ ', ' $b$ ', and carotenoids contents have also been reported to be affected by air pollutants [78-84]. Similarly, the leaves of vegetables such as cauliflower, okra, cabbage, spinach, radish, and brinjal were also affected [85-87]. According to Azmat et al. [84], automobile pollutants also affect the morphological glabrous hairs. Contamination is increasing in Quetta because of high automobile use, strongly affecting the Vitis vinifera (grapes) plants [88,89]. Leaf surfaces are also affected due to different trace elements settling on the leaf surfaces and because of gaseous discharges from road traffic. Therefore, road-side plants are main receivers and reservoirs of all vehicular discharges. Heavy metal automobiles pollutants are highly toxic and reduce growth and morphological characteristics. Ahmad et al. [90] proved that cadmium displayed $5 \mathrm{mg} \mathrm{L}^{-1}$ toxicity in case of root and shoot growth. Flowers of Nuttall's larkspur (Delphinium nuttallianum), Lewis flax (Linum lewisii), scarlet gilia (Ipomopsis aggregata), and sulphur paintbrush (Castilleja sulphurea) growing 1-2 $\mathrm{m}$ from a road were prone to more dust and less pollen than those $40-50 \mathrm{~m}$ away. This dust accumulation on flowers was significantly observed to affect pollination. Energy developmental projects have affected the Uinta Basin, the Colorado Plateau, and other areas of North America. These roads have enhanced the dust loads on plants and pollinators, which reduced plant growth and reproduction [91]. Lewis et al. studied the effects of an unlaid roads on the reproduction and growth of an endemic shrub [92].

\section{Impact of Road-Side Plants on Minimizing Vehicular Emissions}

While vehicular pollution as listed above has been adversely affecting roadside and highway vegetation. Plants do also contribute significantly and play a role in interfacing and reducing automobile-induced pollution. Vegetation directly/indirectly affects air quality. We briefly present reports of these plant-based impacts. Plants act as efficient filters of road dust $[93,94]$. Shetye and Chaperkar [95] employed plants for monitoring dust in Bombay. Their report confirms that leaves of Mirabilis were able to capture dust because of its epidermal hairs. Erythrina, Mangifera indica, Polyalthia, and Thespesia growing in Bombay were proven for their (leaves) reliability as dust indicators. Das et al. [96] conducted an elaborate study on the potential of Indian ornamentals and avenue trees to collect dust. His work confirmed that Ficus, Mangifera, Tectona, and Polyathia were better dust collectors. Das et al. [96] reported that the upper surface of leaves gathered more dust.

Trees are capable of removing gaseous air pollution via stomata, while plant surfaces also assist in removal of gaseous pollutants [97]. Trees intercept airborne particles and resuspend it in to the atmosphere, these particles are washed off by rain, or return to the ground owing to leaf and twig fall. In urban areas with 100\% tree cover, short-term improvements in air quality (one hour) from pollution were observed. Removal of pollutants by trees was as high as $13 \%$ for particulate matter, $14 \%$ for sulfur dioxide, $15 \%$ for ozone, $8 \%$ for nitrogen dioxide, and $0.05 \%$ for carbon monoxide [98].

Vegetation are an important sink for the atmospheric pollutants. $\mathrm{SO}_{2}, \mathrm{NO}_{2}$ and $\mathrm{NH}_{3}$, $\mathrm{O}_{3}$, and $\mathrm{HF}$, metabolize readily, producing several damaging effects. Carbon dioxide, a combustion pollutant, acts as an essential ingredient of photosynthesis. Carbon monoxide is absorbed in gaseous phase. It is known that grass-like vegetation better absorbs several gaseous pollutants like nitrogen dioxide, sulfur dioxide, and ozone from the polluted air. Calculated on a $12 \mathrm{~h}$ exposure basis [99], maize was reported to absorb $0.2 \mathrm{~g} / \mathrm{m}^{2}$ of ozone; bean, $0.52 \mathrm{~g} / \mathrm{m}^{2}$ of $\mathrm{CO}$; alfalfa, $0.17 \mathrm{~g} / \mathrm{m}^{2}$ of $\mathrm{NO}_{2}$; and grasslands, $0.17 \mathrm{~g} / \mathrm{m}^{2}$ of $\mathrm{SO}_{2}$ from a 
polluted area. Plants in turn can also be used as an air pollution indicator [100,101], as they can effectively adsorb air particles [102-106] and reduce air pollutants [107].

Dust can affect the aerial parts of plants. The size of the particles and their characteristics affect plants. Plants vary in their ability to collect particles from air [108,109], larger dust particles are easily filtered by plants than fine particles [110]. Unpaved roads produce more dust [111] and unpaved roads with vehicular traffic will obviously produce more dust than those without. Authors [112] have reported that there was about $10 \mathrm{gm}^{-2}$ day $^{-1}$ logarithmic decline in dust deposition, in an unpaved road in Alaska. Leaf is the most vulnerable part for attack of air pollutants compared to other plant parts, because all the crucial physiological processes are conducted by the leaf. Further, this is why the leaf can be marked as an excellent indicator of air pollution. The plant-based response to dust, varies species to species, because deposition of dust varies within plant species due to leaf orientation, phyllotaxy, leaf surface geometry, cuticular and epidermal features, height and canopy of roadside plants, leaf pubescence $[44,93,113,114]$. Dust accumulation of roadside plants may induce them to adopt to adaptive responses through changing their morphologies or physiologies.

Air pollution due to vehicular emission $[37,115,116]$ affects all varieties of road-side plants. Cassia siamea plants growing in polluted localities in Agra city, exhibited significant differences in their flowering phonology and floral morphology [117]. Air pollution stress affects stomatal closure, reducing $\mathrm{CO}_{2}$ availability in leaves and $\mathrm{C}$ fixation. This is why the net photosynthetic rates of roadside plants can be used as an indicator of the impacts of air pollutants on tree growth [118]. In accordance with their sensitivity levels, plants could alter the biochemical processes and lead to accumulation of certain metabolites [119]. $\mathrm{SO}^{2-}, \mathrm{NO}_{\mathrm{x}}$, and $\mathrm{CO}_{2}$ and suspended particulate pollutants from automobile exhausts, absorbed by the leaves, affect chlorophyll and carotenoids, which in turn affect plant productivity [120-125]. The photosynthetic pigments can also be used as bioindicators of automobile pollution. Deleterious effects are caused by reactive oxygen species (ROS) in plants [124]. It has been reported that proline act as a free radical scavenger to protect plants from damage by oxidative stress and is said to accumulate under environmental stress [126]. Tankha and Gupta [127] confirmed an increase in proline with increasing $\mathrm{SO}_{2}$ concentration and a similar increase in proline in Albizia lebbeck and Callistemon citrinus has also been reported [116]. All these above-mentioned automobile-induced responses of plants can be in turn used as pollution indicators.

Reports confirm that dust can influence plant community structures. Parish [128] reported a shift in plant community close to some cement factories [129]. Lotschert and Kohm [130] reported bark $\mathrm{pH}$ alterations and changes in $\mathrm{Ca}_{2}$ content in the bark of trees on long-term exposure to dust. Some field-based studies have confirmed the damages on road-side plants [131] and agricultural crops grown beside highway traffic in London in the 1980s [132].

The above-mentioned information emerged as a consequence of a handful of researchers and their reports published till date. The negative effects are not merely limited to what has been reported. This review found that the research focus has been basically very limited and ideally lacking in this area. Not just highways, but even plants all along walkways and our neighborhood are vulnerable to the fury of the vehicular emissions.

Table 1 summarizes the list of road-side plants that have been affected through vehicular emissions. There are definitely many more road-side plants that are affected and are yet to be observed and reported. This review envisions a scientific awareness to look into the magnitude of damage incurred so that remedial measures may be considered. 
Table 1. Effect of vehicular pollution on road-side plants.

\begin{tabular}{|c|c|c|c|}
\hline Source of Pollution & Negative Impacts & Plants Species Affected & References \\
\hline \multirow{9}{*}{ Vehicular emissions } & $\begin{array}{l}\text { Reduced growth and reduction } \\
\text { in leaf numbers }\end{array}$ & Abies alba & {$[5]$} \\
\hline & $\begin{array}{l}\text { Variations in leaf anatomy, } \\
\text { morphology, and decreased } \\
\text { chlorophyll contents }\end{array}$ & Syzgium cumini & [9] \\
\hline & Damages on flowers and seeds & Ceasalpinia sepiaria & [11] \\
\hline & Increased absorption & Rhododendron catabiese & [18] \\
\hline & Increased leaf temperature & $\begin{array}{l}\text { Popular tremula, Betula pendula, Acer campestre, } \\
\text { Prunus avium, Quercus spp, Alnus glutinosa }\end{array}$ & [26] \\
\hline & $\begin{array}{l}\text { Stomata blocked and reduction in } \\
\text { diffusion resistance of the leaf }\end{array}$ & $\begin{array}{l}\text { Populus tremula, Betula pendula, } \\
\text { Alnus glutinosa, Fraxinus exselsior }\end{array}$ & [26] \\
\hline & $\begin{array}{l}\text { Dimensions of guard and epidermal } \\
\text { cells reduced }\end{array}$ & Pongamia pinnata & [29] \\
\hline & $\begin{array}{l}\text { Reduced total chlorophyll and } \\
\text { protein content in leaves }\end{array}$ & $\begin{array}{c}\text { Azadirachta indica, Ficus religiosa, } \\
\text { Ficus benghalensis, Terminalia } \\
\text { catapa }\end{array}$ & {$[40]$} \\
\hline & $\begin{array}{l}\mathrm{SO}_{2} \text { concentrations in emissions } \\
\text { increase proline in plants }\end{array}$ & Albizia lebbeck and Callistemon citrinus & [116] \\
\hline \multirow{4}{*}{ Vehicle induced dust } & $\begin{array}{l}\text { Dust covered leaves absorbed } \\
\text { more radiation }\end{array}$ & Hedera helix, Rhododendrom catawbinse & {$[77]$} \\
\hline & Leaves damaged & $\begin{array}{l}\text { Cauliflower, okra, cabbage, spinach, radish, } \\
\text { and brinjal }\end{array}$ & [85-87] \\
\hline & $\begin{array}{l}\text { Flowers covered by dust and having } \\
\text { decreased pollen }\end{array}$ & $\begin{array}{c}\text { Nuttall's larkspur (Delphinium nuttallianum), } \\
\text { Lewis flax (Linum lewisii), scarlet gilia } \\
\text { (Ipomopsis aggregata), and sulphur paintbrush } \\
\text { (Castilleja sulphurea) }\end{array}$ & [90] \\
\hline & Dust collectors & Ficus, Mangifera, Tectona, and Polyathia & [96] \\
\hline Vehicular dust & $\begin{array}{l}\text { Affects flowering phonology and } \\
\text { floral morphology }\end{array}$ & Cassia siamea & [117] \\
\hline
\end{tabular}

Vehicle induced dust—dust rising through physical movement of vehicles; vehicular dust—dust in emissions.

\section{The Nanoparticle Aspect of Automobile Exhausts}

While the gaseous and dust fractions of automobile exhausts have been somewhat explored and presented, the nanoparticular aspects involved in vehicular emissions are relatively less documented. Diesel and automobile exhaust have been reported as the primary sources of atmospheric nano- and microparticles [133]. Vehicular exhausts are said to contain spherical nanoparticles in the size ranges of 20-130 $\mathrm{nm}$ in diesel engines and $20-60 \mathrm{~nm}$ in case of gasoline. Carbon nanotubes and fibers were recently found to be present in engine exhaust as a by-product of diesel combustion [134-136]. A high concentration of nanoparticles was localized on expressways, showing that vehicular pollution is a source of nanoparticles. The daily profile of nanoparticles could be directly correlated with local vehicle usages [137]. High pollution, proximity to high-traffic, increased the concentration of nanoparticles, several times [138]. These reports confirmed the presence of nanomaterial in automobile exhausts. Childhood cancers, myocardial infarction heart attack, lung cancer [139], and activation of one or more signaling pathways that cause proinflammatory, prothrombotic, and hemolytic breakdown of red blood cells responses are few of the noteworthy exhausts-based nanomaterial toxicity reports [140,141]. Carbon nanoparticles, nanotubes, and nanospheres from exhausts have been well documented for their human and animal health and welfare. Although the adverse effects of carbon nanotubes and particles on plants are well known [142-147], this review found that in- 
vestigations specifically on the effect of road transport-induced carbon nanomaterials on roadside plants were lacking.

Concerns on carbon nanomaterial-based toxicity on highway plants, like avenue trees, shrubs, weeds are already pressing. This concern gathers seriousness, when the emissions-induced carbon nanomaterial will affect edible and staple food crops (Figure 3). In most of the developing countries, farmland and agricultural fields lie in close proximity to highways and road, in this way, the affected plants are no longer merely roadside plants, but edible crops. This way, the automobile-induced carbon toxicity has chances of entering the food chain and affecting human health and welfare. The potential toxicity of carbon has been discussed in our earlier review [148]. A study conducted by Lin et al. [147] showed that C70 fullerenes and multi walled carbon nanotubes (MWNT) delayed flowering in rice by a month and reduced the yield of exposed rice plants. Exposure of wheat plants to carbon nanotubes made them susceptible to uptake of pollutants [149]. Moreover, it is also reported that carbon nanotubes can penetrate the cell wall of the roots of wheat plants, making a pipeline for entry of pollutants into the cells. The most disastrous projection is when seeds exposed to C70 fullerenes passed on the carbon nanomaterial to the next generation seeds. Rice seeds exposed to SWCNTs, MWCNTs, and C70 showed the presence of carbon nanomaterials in their second generation. The highest was in the seed, followed by the root and stem and leaf respectively. This confirms the transmittance of C70 to the next generation. Carbon NMs accumulate in roots and can delay germination of rice seeds by a month $[150,151]$. Given the toxicity fact file of carbon nanomaterials and that these nanomaterials are present in automobile exhausts, it is rather disappointing to see that not much attention has been paid to unravel the status quo of the carbon nanomaterial effects of road-side vegetation and agricultural crops.

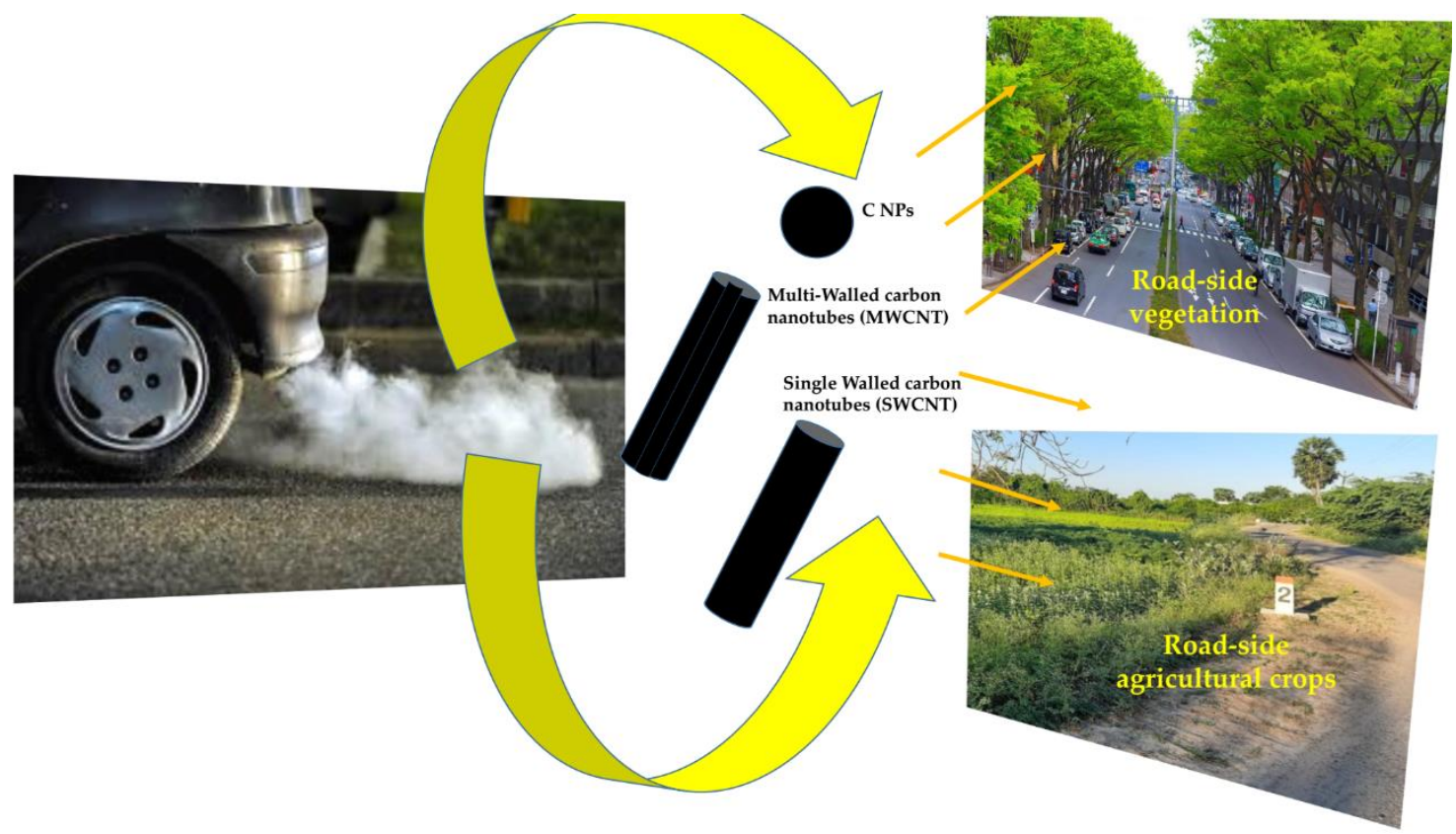

Figure 3. Carbon nanomaterials reported in automobile exhausts that can affect all road-side vegetation and moreso, road-side agricultural crops, indirectly entering the food chain of man.

\section{Future Perspectives and Conclusions}

Plants being the primary producers and the first level of the food chain need to be sustained with care and concern. The use of two wheelers is steadily on the increase, especially in underdeveloped and developing countries. Taking into account the economicity of two wheelers, one can only expect an escalation in the purchase and utility of two wheelers much more than four wheelers. As discussed above, two wheelers are sort of the major contributors to air pollution. 
A clear understanding of the automobile-induced pollution on plants can aid in the planning of those plants that are resistant to automobile, as roadside plants. Moreover, constant monitoring of the plant-based responses and manifestation of bio indicators can help act as bio indicators, which can in turn help estimating the risk of pollution to that environment. Proper maintenance of two wheelers can help reduce automobile exhaust. Detailed studies are needed to evaluate what vehicle types are contributing towards affecting road-side plants.

Most importantly, this review calls to attention the need to assess the carbon nanomaterial load of automobile exhausts and further the impact of these automobile exhaust borne carbon nanomaterials on roadside vegetation. More so, since no reports exist on the effect of such vehicular exhaust induced carbon nanomaterials on road-side agricultural fields, this grey area needs research focus to gain appropriate future perspective directions. Moreover, there is lack of quantitative data and information in this direction. Such data, would be helpful in precisely determining the impact of plants on trapping vehicular emissions as well as understanding the impact of emissions on various plants.

Figure 4 gives an overview of the current scientific awareness on (i) impact of automobiles on road-side vegetation, (ii) impact of road-side vegetation on automobile induced pollution, and (iii) impact of carbon nanomaterials on road-side plants and agricultural crops. When the gaseous pollutant, dust aspects of automobile exhausts have been studied extensively and reviewed elaborately, hardly any reports exist on assessing the carbon nanomaterial-based aspect of automobile induced pollution and its effect on plants. This review draws the attention of researchers towards this lacuna. The actual gravity of the situation should be disclosed, so that appropriate mitigation methods can be assorted to.

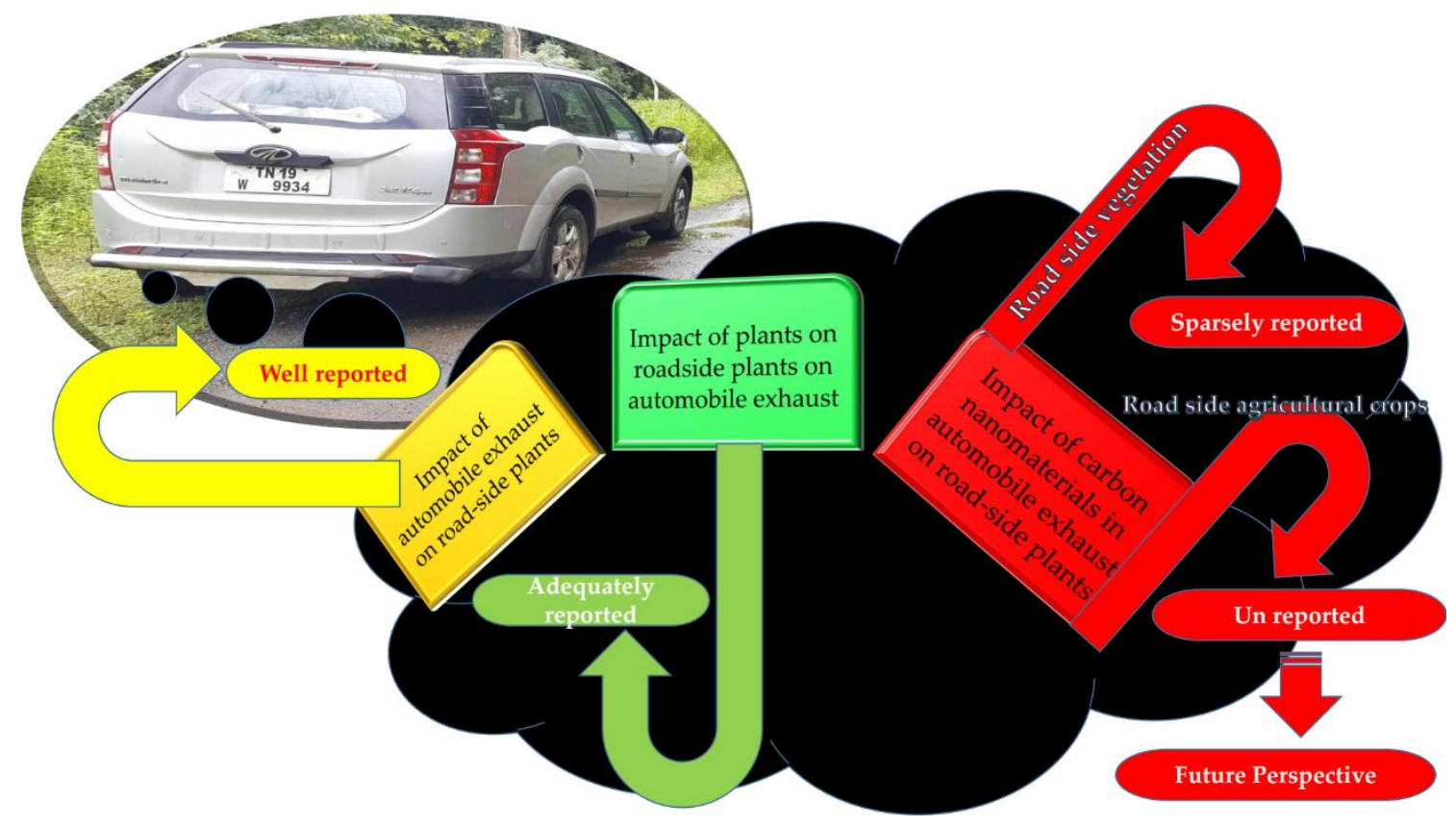

Figure 4. Status quo of scientific awareness on (i) impact of automobiles on road-side vegetation, (ii) impact of road-side vegetation on automobile induced pollution, and (iii) impact of carbon nanomaterials on road-side plants and agricultural crops, the least disclosed is the impact on road-side agricultural crops. This aspect is the key direction for future perspectives.

There is an urgent need for answers to queries such as: what is the perimeter of dispersal of the automobile emission? This information is needed in order to come up with guidelines to plan road infrastructure designing, so that vegetation can be allotted spots beyond the emission plume. This calls for research in this direction, which will spell out the minimum distance that vegetation need to avoid road and highway impacts and evade the emission plume. This emission plume cannot be standardized, it will vary with the automobile traffic of each region, and hence local research groups need to get to determine 
this, so that guidelines for road-side vegetation, specific for each locality, can be dictated. Especially with respect to agricultural crops, on whom the impact of vehicular emissions could be more detrimental, there needs to be clear cut guidelines issued, which will dictate the minimum distance these agricultural plantations need to be from the road to escape the impact of the vehicular emissions. This will need research groups working out impacts and intensity of impacts specifically with respect to various food crops. Thus, there are a lot of unknowns that need to be addressed through focused research work in this direction and yet as this review points out, nothing much is happening and no real progress is in the air. This review hopes to draw the attention of researchers to concentrate on addressing the highlighted issues.

Author Contributions: Conceptualization, data curation, writing—original draft preparation, writing review and editing, M.M., J.G., I.S.; supervision, D.-H.K. All authors have read and agreed to the published version of the manuscript.

Funding: This research received no external funding.

Institutional Review Board Statement: Not applicable.

Informed Consent Statement: Not applicable.

Acknowledgments: This work was supported by the KU Research Professor Program of Konkuk University.

Conflicts of Interest: The authors declare no conflict of interest.

\section{References}

1. Yunus, M.; Singh, N.; Iqbal, M. Global status of air pollution: An overview. In Plant Response to Air Pollution; Yunus, M., Igbal, M., Eds.; John Wiley and Sons, Ltd.: New York, NY, USA, 1996; pp. 1-34.

2. Santra, S.C. Environmental Science; New Central Book Adency (P) Ltd.: Kolkata, India, 2001; pp. 301-314.

3. World Health Organization (WHO). The World Health Report 2002: Reducing Risks, Promoting Healthy Life; WHO: Geneva, Sweden, 2002.

4. Treshow, M.; Bell, J.N.B. Air Pollution and Plant Life; Wiley: New York, NY, USA, 2002; p. 34.

5. Swami, A. Impact of Automobile Induced Air Pollution on roadside vegetation: A Review. ESSENCE Int. J. Environ. Rehabil. Conserv. 2018, IX, 101-116. [CrossRef]

6. Agarawal, M.; Agrawal, S.B. Impact of atmospheric pollution on plant diversity. Botanica 1999, 49, 38-46.

7. Rawat, R. Effects of Air Pollution on Some Road Side Plants of Mussorie Hills. Master's Thesis, Gurukula Kangri University, Haridwar, India, 2001.

8. Bakshi, N. Study on Road Side Air Quality of Jammu City. Master's Thesis, Submitted in Department of Environmental Sciences, Jammu University, Jammu, India, 2001.

9. Raina, A.K.; Sharma, A. Effects of vehicular pollution on the leaf micro-morphology, anatomy and chlorophyll contents of Syzygium cumini L. Indian J. Environ. Protect. 2003, 23, 897-902.

10. Raina, A.K.; Singh, C.D.; Deepika, R.; Kumar, A. Effect of vehicular exhaust on some trees in Jammu-I. Indian J. Environ. Ecolplan. 2004, 8, 149-152.

11. Nithamathi, C.P.; Indira, V. Impact of air pollution on Ceasalpinia sepiaria Linn. In Tuticorin city. Indian J. Environ. Ecolplan. 2005, $10,449-452$.

12. Thomas, M.D. Gas damage to plants. Ann. Rev. Plant Physiol. 1951, 2, 293-322. [CrossRef]

13. Mapson, L.W. Metabolism of ascorbic acid in plants: Function. Ann. Rev. Plant Physiol. 1958, 9, 119-150. [CrossRef]

14. Walker, E.K.; Vickery, L.S. Influence of sprinkler irrigation on the incidence of weather fleck on flue-cured tobacco in Ontario. Can. J. Plant Sci. 1961, 41, 281-287. [CrossRef]

15. Godzik, S.; Piskornik, Z. Transpiration of Aesculus hippocastanum leaves from areas of various air pollution. Bull. Acad. Pol. Sci. Ser. B 1966, 14, 181-184.

16. Dean, C.R.; Davis, D.R. Ozone and soil moisture in relation to the occurrence of weather fleck on Florida cigar-wrapper tobacco in 1966. Plant Dis. Rep. 1967, 51, 72-75.

17. Majernik, O.; Mansfield, T.A. Direct effect of $\mathrm{SO}_{2}$ pollution on the degree of opening of stomata. Nature 1970, 227, 377-378. [CrossRef] [PubMed]

18. Eller, B.M. Road dust induced increase of leaf temperature. Environ. Pollut. 1974, 13, 99-107. [CrossRef]

19. Ashmore, M.R.; Bell, J.N.B.; Reily, C.L. A survey of ozone levels in the British Isles using bioindicator plants. Nature 1978, 276, 813-814. [CrossRef]

20. Black, C.R.; Black, V.J. The effect of low concentrations of sulphur dioxide on stomatal conductance and epidermal cell survival in field bean (Vicia faba L.). J. Exp. Bot. 1979, 30, 291-298. [CrossRef] 
21. Reich, P.B.; Lassoie, J.P. Effects of low level ozone exposure on leaf diffusive conductance and water use efficiency caused be air pollutants. Plant Cell Environ. 1984, 7, 661-668. [CrossRef]

22. Mansfield, T.A. The physiology of stomata: New insights into old problems. In Plant Physiology, a Treatise; Vol IX: Water and Solutes in Plants; Academic Press, Inc.: Orlando, FL, USA, 1986; pp. 155-224.

23. Mott, K.A. Do stomata respond to $\mathrm{CO}_{2}$ concentrations other than intercellular? Plant Physiol. 1988, 86, 200-203. [CrossRef] [PubMed]

24. Neighbour, E.A.; Cottam, D.A.; Mansfield, T.A. Effects of sulfur dioxide and nitrogen dioxide on the control of water loss by birch (Betula spp.). New Phytol. 1988, 108, 149-157. [CrossRef]

25. Greszta, J.; Barszcz, J.; Niemtur, S. Evaluation of damage to montane forests in southern Poland. In Air Pollution and Forest, Decline; Bucher, J.B., BucherWallin, I., Eds.; Eidgeniissische Anstalt fur das Forstliche Versuchswesen: Birmensdorf, Switzerland, 1989; pp. 41-50.

26. Fluckiger, W.; Braun, S. Nitrogen deposition in Swiss forests and its possible relevance for leaf nutrient status, parasite attacks and soil acidification. Environ. Pollut. 1998, 102, 69-76. [CrossRef]

27. Farage, P.K.; Long, S.P.; Lechner, E.G.; Baker, N.R. The sequence of change within the photosynthetic apparatus of wheat following short-term exposure to ozone. Plant Physiol. 1991, 95, 529-535. [CrossRef] [PubMed]

28. Beerling, D.J.; Chaloner, W.G. Stomatal density responses of Egyptian Olea europaea L. leaves to $\mathrm{CO}_{2}$ change since $1327 \mathrm{BC}$. Ann. Bot. 1993, 71, 431-435. [CrossRef]

29. Rai, P.; Mishra, R.M. Effect of urban air pollution on epidermal traits of road side tree species, Pongamiapinnata (L.). Merr. J. Environ. Sci. Toxicol. Food Technol. 2013, 2, 2319-2402.

30. Darley, E.F.; Dugger, W.M.; Mudd, J.B.; Ordin, L.; Taylor, O.C.; Stephens, E.R. Plant damage derived from automobiles. Am. Med. Assoc. Arch. Environ. Health 1963, 6, 761-770. [CrossRef] [PubMed]

31. Nivova, D.J.; Dushkova, P.I.; Kovacheva, C.V. Anatomical, morphological studies of Platanus acerifolia at various degrees of air pollution. Ekologiya (Sofia) 1983, 6, 35-47.

32. Inamdar, J.A.; Chaudahri, G.S. Effects of environmental pollutants of leaf epidermis and leaf architecture of Peristrophe bicalyculata. J. Plant Anat. Morphol. 1984, 1, 1-8.

33. Iqbal, M.Z. Cuticular and anatomical studies of white clover leaves from clean and air-polluted areas. Pollut. Res. 1985, 4, 59-61.

34. Karenlampi, L. Relationships between macroscopic symptoms of injury and cell structural changes in needles of ponderosa pine exposed to air pollution in California. Ann. Bot. Fenn. 1986, 23, 255-264.

35. Godzik, S.; Halbwacks, G. Structural alterations of Aesculus hippocastanum leaf surface by air pollutant. ZP Flanzekr. Pflanzenchutz 1986, 93, 590-596.

36. Krause, C.R.; Dochinger, L.S. Sulphur accumulation in red maple Acer rubrum leaves from clean and air polluted areas. Pollut. Res. 1987, 4, 59-61.

37. Bhatti, G.H.; Iqbal, M.Z. Investigations into the effect of automobile exhausts on the phenology, periodicity and productivity of some roadside trees. Acta Soc. Bot. Pol. 1988, 57, 395-399. [CrossRef]

38. Gupta, M.C.; Ghouse, A.K.M. Effects of coal smoke pollutants from different sources in the growth, chlorophyll content, sten anatomy and cuticular traits of Euphorbia hirta L. Environ. Pollut. 1988, 47, 221-230. [CrossRef]

39. Jahan, S.; Zafar, I. Morphological and anatomical studies o leaves of different plants affected by motor vehicles exhaust. J. Islamic Acad. Sci. 1992, 5, 21-23.

40. Wagh, N.; Shukla, P.V.; Tambe, S.B.; Ingle, S. Biological monitoring of roadside plants exposed to vehicular pollution in Jalgaon city. J. Environ. Biol. 2006, 37, 419-421.

41. Renjini, M.B.J.; Janardhanan, K. Effect of some heavy metals on seed germination and early growth of ground nut, sunflower and ginger. Geobiosystems 1989, 16, 164-170.

42. Pyatt, F.B. Lichens as indicators of air pollution in a steel producing town in South Wales. Environ. Pollut. 1970, 1, 45-56. [CrossRef]

43. Feder, W.A. Plant response to chronic exposure to low levels of oxidant type air pollution. Environ. Pollut. 1970, 1, 73-79. [CrossRef]

44. Davison, A.; Blakemore, J. Factors determining fluoride accumulation in forage. In Effects of Air Pollution on Plants; Mansfield, T., Ed.; Cambridge University Press: Cambridge, UK, 1976; pp. 17-30.

45. Furukawa, A.; Isoda, O.; Iwaki, H.; Totsuka, T. Interspecific difference in resistance to sulfur dioxide. In: Studies on the effects of air pollutants on plants and mechanisms of phytotoxicity. Res. Rep. Natl. Inst. Environ. Stud. Jpn. 1980, 11, $113-126$.

46. Vora, A.B.; Bhatnagar, A.R. Comparative study of dust fall on the leaves in high pollution and low pollution areas of Ahmedabad. Pollut. Res. 1986, 5, 153-157.

47. Rao, S. Effect of cement dust pollution on plants. J. Swamy Botl. Club. 1991, 8, 35-39.

48. Gunamani, T.; Gurusamy, R.; Swaminathan, K. Effect of cement dust pollution on the thermal appendages and anatomy of leaves in some herbaceous plants. J. Swamy Botl. Club. 1991, 8, 79-85.

49. Gupta, A.K.; Mishra, R.M. Effect of lime klin's air pollution on some plant species. Pollut. Res. 1994, 13, 1-9.

50. Ignacimuthu, S.; Muralaytharan, V. Effect of cement kiln on dust on root tip cells of Allium cepa. J. Ecotoxico. Environ. Monit. 1994, $4,263-265$. 
51. Palaniswamy, M.; Gunamani, T.; Swaminathan, K. Effect of air pollution caused by automobile exhaust gases on crop plants. Proc. Acad. Environ. Biol. 1995, 4, 255-260.

52. Pandey, D.D.; Satya, N. Effect of stone crusher dust pollution on grain characteristics of maize. Environ. Ecol. 1995, 13, 901-903.

53. Shamnughavel, P. Effect of cement dust on stomatal structure. Ecol. Environ. Conserv. 1995, 1, 7-9.

54. Urna, C.H.; Rao, R.T.V. Effect of cement dust kiln on Hibiscus cannabinus L. Geobiosystems 1996, 23, 59-64.

55. Vijaywargiya, A.; Pandey, G.P. Effect of cement dust pollution on soybean physiological and biochemical. Ecol. Environ. Conserv. 1996, 2, 143-145.

56. Karpate, R.R.; Chaudhary, A. Effect of thermal power station's waste on wheat. J. Environ. Biol. 1997, 18, 1-10.

57. Pandey, D.D.; Nirala, A.K.; Gautam, R.R. Impact of stone crusher dust pollution on maize crops. Indian J. Environ. Ecol. Plan. 1999, 2, 43-46.

58. Jha, R.K. Effect of coal dust pollution on the vegetation around Dhanbad coalfield. Biojournal 1999, 11, 59-61.

59. Kashyap, M.K.; Jain, A.; Banerjee, S.K. Foliar biochemical composition of some plant species growing near thermal power plant. Indian J. Environ. Sci. 2001, 5, 11-17.

60. Srinivas, N.; Chandrapaul, B.; Rao, P. Biomonitoring of dust pollution. Nat. Environ. Pollut. Technol. 2002, 1, 27-30.

61. Banerjee, S.; Singh, A.K.; Banerjee, S.K. Impact of flyash on foliar chemical and biochemical composition of naturally occurring ground flora and its possible utilization for growing tree crop. Indian For. 2003, 129, 964-977.

62. Vijaywargiya, A.; Pandey, G.P. Effect of cement dust on soyabean, Glycine max (L.) merr. and maize, Zea mays Linn. In fluorescence studies. Geobiosystems 2003, 30, 209-212.

63. Vardaka, E.; Cook, C.M.; Lanaras, T.; Sgardelis, S.P.; Pantis, J.D. Effect of dust from a limestone quarry on the photosynthesis of Quercus coccifera, an evergreen schlerophyllous shrub. Bull. Environ. Contam. Toxicol. 1995, 54, 414-419. [CrossRef]

64. Auerbach, N.; Walker, M.; Walker, D. Effects of roadside disturbance on substrate and vegetation properties in arctic tundra. Ecol. Appl. 1997, 7, 218-235. [CrossRef]

65. Hope, A.S.; Fleming, J.B.; Stow, D.A. Tussock tundra albedos on the north slope of Alaska: Effects of illumination, vegetation composition, and dust deposition. J. Appl. Meteorol. 1991, 30, 1200-1206. [CrossRef]

66. Gupta, G.P.; Kumar, B.; Singh, S.; Kulshrestha, U.C. Deposition and Impact of Urban Atmospheric Dust on Two Medicinal Plants during Different Seasons in NCR Delhi. Aerosol. Air Qual. Res. 2016, 16, 2920-2932. [CrossRef]

67. Sharifi, M.R.; Gibson, A.C.; Rundel, P.W. Surface dust impacts on gas exchange in Mojave Desert shrubs. J. Appl. Ecol. 1997, 34, 837-846. [CrossRef]

68. Wijayratne, U.C.; Scoles-Scilla, S.J.; Defalco, L.A. Dust deposition effects on growth and physiology of the endangered Astragalus jaegerianus (Fabaceae). Madroño 2009, 56, 81-88. [CrossRef]

69. Oblisami, G.; Pathmanabhan, G.; Padmanabhan, C. Effect of particulate pollutants from cement kiln on cotton plant. Indian J. Air Pollut. Contr. 1978, 1, 91-94.

70. Hirano, T.; Kiyota, M.; Aiga, I. Physical effects of dust on leaf physiology of cucumber and kidney beans plants. Environ. Pollut. 1995, 89, 255-261. [CrossRef]

71. Borka, G. The effect of cement dust pollution on growth and metabolism of Helianthus annuus. Environ. Pollut. Ser. A 1980, 22, 75-79. [CrossRef]

72. Steinhubel, G.; Halas, L. Poruchy v tvorbe susiny pri zvysenych teplotach vyvolanych v listoch drevin prasnou imisiou. Lesnicky Casopis 1967, 13, 365-383.

73. Guggenheim, R.; Fluckiger, W.; Fluckiger-Keller, H.; Oertli, J.J. Pollution on leaf surfaces in the vicinity of a motorway. Ber. Umwelt Bundes Amt. 1980, 79, 462-468.

74. Eveling, D.W. Effects of spraying plants with suspensions of inert dusts. Ann. Appl. Biol. 1969, 64, 139-151. [CrossRef]

75. Kameswaran, S.; Gunavathi, Y.; Krishna, P.G. Dust pollution and its influence on vegetation-a critical analysis. Res. J. Life Sci. Bioin. Pharm. Chem. Sci. 2019, 5, 341-363.

76. Hussain, N.; Farrukh, A.; Zahir, T.; Zaman, S.; Saijque, A.R. Air borne particulate and their effect on some road side trees of Peshawar city. Sarhad J. Agric. 1994, 10, 85-91.

77. Eiler, B.M. Influences of road dust on the energy balance of leaves. Pflanzen Biol. 1997, S1, 9-11.

78. Singh, S.N. Role of foliar urea spray in reducing pollutant injury to plants. Environ. Conser. 1981, 8, 183-186. [CrossRef]

79. Vij, B.M.; Trivedi, L.; Shevade, A.; Dubey, P.S. Chlorophyll damage in tree species due to air pollution. Biol. Bull. India 1981, 3, 193-194.

80. Malabari, A.A.; Ahmad, Z.; Saquib, M. Effect of air pollution on Ganaphalium pensylvanicum wild-A crop land weed. Geobios 1991, 18, 7-10.

81. Anbazhagan, M.; Bhagwat, K.A. Studies on the progeny of rice plants grown at an unpolluted and polluted site. Environ. Pollut. 1991, 69, 17-23. [CrossRef]

82. Garty, J.; Karary, Y.; Harel, J. The impact of air pollution on the integrity of cell membranes and chlorophyll in the lichen Ramalina duriaei (de not.) bagl. transplanted to industrial sites in Israel. Arch. Environ. Contam. Toxicol. 1993, 24, 455-460. [CrossRef]

83. Krishnamurthy, R.; Srinivas, T.; Bhagwat, K.A. Effect of air pollution on some band trees of the agricultural lands. J. Environ. Biol. 1994, 15, 97-106.

84. Azmat, R.; Haider, S.; Nasreen, H.; Aziz, F.; Riaz, M. A viable alternative mechanism in adapting the plants to heavy metal environment. Pak. J. Bot. 2009, 41, 2729-2738. 
85. Öztürk, M.A.; Turkam, Y. Heavy Metal Accumulation by Plants Growing Alongside the Motor Roads: A Case Study from Turkey'. In Plants as Biomonitors: Indicators for Heavy Metals in Terrestrial Environments; Markert, E., Ed.; VCH: Weinheim, Germany, 1993; pp. 515-522.

86. Screbo, R.; Possenti, L.; Lampugnami, L.; Ristoni, T.; Barale, R.; Barghigiani, C. Lichen (Xanthori apariienta), biomonitoring of trace elements contamination and air quality assessment in Livorna Province (Tscany, Italy). Sci. Total Environ. 2002, 286, 27-40.

87. Aslan, A.; Cicek, A.; Yazici, K.; Karagoz, Y.; Turan, M.; Akkus, F.; Yildrim, O.S. The assessment of lichens as bioindicator of heavy metal pollution from motor vehicles activities. Afr. J. Agric. Res. 2011, 6, 1698-1706.

88. Leghari, S.K.; Zaidi, M. Effect of air pollution on the leaf morphology of common plant species of Quetta city. Pak. J. Bot. 2013, $45,447-454$.

89. Steubing, L.; Fangmeier, A. $\mathrm{SO}_{2}$ Sensitivity of Plant Communities in a Beech Forest. Environ. Pollut. 1987, 44, 297-306. [CrossRef]

90. Ahmad, I.; Akhtar, M.J.; Zahir, Z.A.; Jamil, A. Effect of cadmium on seed germination and seedling growth of four wheat (Triticum aestivum L.) cultivars. Pak. J. Bot. 2012, 44, 1569-1574.

91. Waser, N.M.; Price, M.V.; Casco, G.; Diaz, M.; Morales, A.S.; Solverson, J. Effects of road dust on the pollination and reproduction of wildflowers. Int. J. Plant Sci. 2017, 178, 85-93. [CrossRef]

92. Lewis, M.; Schupp, E.; Monaco, T. Road Dust Correlated with Decreased Reproduction of the Endangered Utah Shrub Hesperidanthus suffrutescens. West. N. Am. Nat. 2017, 77, 430-439. [CrossRef]

93. Farmer, A.M. The effects of dust on vegetation-A review. Environ. Pollut. 1993, 79, 63-75. [CrossRef]

94. Beckett, K.P.; Freer Smith, P.H.; Taylor, G. Particulate pollution capture by urban trees: Effect of species and winds peed. Glob. Chang. Biol. 2000, 6, 995-1003. [CrossRef]

95. Shetye, R.P.; Chaphekar, S.B. Some estimations on dust fall in the city of Bombay, using plants. In Progress in Ecology; Agarwal, V.P., Sharma, V.K., Eds.; Today and Tomorrow's Printers and Publishers: New Delhi, India, 1980; pp. 61-70.

96. Das, T.N.; Bhaumik, A.; Ghosh, A.; Chakravarti, A. Tree as dust filters. Sci. Today 1981, 15, 1921.

97. Smith, W.H. Air Pollution and Forests: Interactions between Air Contaminants and Forest Ecosystems; Springer: New York, NY, USA, 1990; p. 618.

98. Nowak, D.; Crane, D. The Urban Forest Effects (UFORE) Model: Quantifying urban forest structure and functions. In Integrated Tools for Natural Resources Inventories in the 21st Century; Hansen, M., Burk, T., Eds.; US Department of Agriculture, Forest Service, North Central Forest Experiment Station: St. Paul, MN, USA, 2000; pp. 714-720.

99. Spedding, D.J. The interaction of gaseous pollutants with materials at the surface of the earth. In Environmental Chemistry; Bockris, J.M., Ed.; Plenum Press: New York, NY, USA, 1976; p. 213241.

100. Ram, S.S.; Kumar, R.V.; Chaudhuri, P.; Chanda, S.; Santra, S.C.; Sudarshan, M.; Chakraborty, A. Physico-chemical characterization of street dust and re-suspended dust on plant canopies: An approach for finger printing the urban environment. Ecol. Indic. 2014, 36, 334-338. [CrossRef]

101. Norouzi, S.; Khademi, H.; Faz Cano, A.; Acosta, J.A. Using plane tree leaves for biomonitoring of dust borne heavy metals: A case study from Isfahan, Central Iran. Ecol. Indic. 2015, 57, 64-73. [CrossRef]

102. Freer-Smith, P.H.; Holloway, S.; Goodman, A. The uptake of particulates by an urban woodland: Site description and particulate composition. Environ. Pollut. 1997, 95, 27-35. [CrossRef]

103. Prusty, B.A.K.; Mishra, P.C.; Azeez, P.A. Dust accumulation and leaf pigment content in vegetation near the national highway at Sambalpur, Orissa, India. Ecotoxicol. Environ. Saf. 2005, 60, 228-235. [CrossRef] [PubMed]

104. Nowak, D.J.; Crane, D.E.; Stevens, J.C. Air pollution removal by urban trees and shrubs in the United States. Urban For. Urban Green. 2006, 4, 115-123. [CrossRef]

105. Jamil, S.; Abhilash, P.C.; Singh, A.; Singh, N.; Behl, H.M. Fly ash trapping and metal accumulating capacity of plants: Implication for green belt around thermal power plants. Landsc. Urban Plan. 2009, 92, 136-147. [CrossRef]

106. Qiu, Y.; Guan, D.; Song, W.; Huang, K. Capture of heavy metals and sulfur by foliar dust in urban Huizhou, Guangdong Province, China. Chemosphere 2009, 75, 447-452. [CrossRef]

107. Hofman, J.; Bartholomeus, H.; Calders, K.; Van Wittenberghe, S.; Wuyts, K.; Samson, R. On the relation between tree crown morphology and particulate matter deposition on urban tree leaves: A ground-based LiDAR approach. Atmos. Environ. 2014, 99, 130-139. [CrossRef]

108. Möller, D. Luft: Chemie, Physik, Biologie, Reinhaltung, Recht; Walter de Gruyter: Berlin, Germany, 2003.

109. Wolf-Benning, U. Kleinräumige und zeitliche Variabilität von Feinstaub und Grobstaub sowie Stickstoffdioxid in Berlin. Berl. Geogr. Arb. 2006, 105, 130.

110. Langner, M. Staubumsatz in verkehrsexponierten Baumkronen und Partikelverteilung in städtischen Grünflächen. Berl. Geogr. Arb. 2007, 109, 1-12.

111. Roberts, J.W.; Watters, H.A.; Mangold, C.A.; Rossano, A.T. Cost and benefits of road dust control in Seattle's industrial valley. J. Air Pollut. Control Assoc. 1975, 25, 948-952. [CrossRef]

112. Brown, J.; Berg, R.L. (Eds.) Environmental Engineering and Ecological Baseline Investigations along the Yukon River-Prudhoe Bay Haul Road; CRREL Report; Army Cold Regions Research and Engineering Laboratory: Hanover, NH, USA, 1980; pp. 19-80.

113. Chaphekar, S.B.; Boralkar, D.B.; Shetye, R.P. Plants for air monitoring in industrial area. In Tropical Ecology and Development; Furtado, J.I., Ed.; I.S.T.E: Kuala Lampur, Malaysia, 1980; pp. 669-675. 
114. Chaturvedi, R.; Prasad, S.; Rana, S.; Obaidullah, S.; Pandey, V.; Singh, H. Effect of dust load on the leaf attributes of the tree species growing along the roadside. Environ. Monit. Assess. 2013, 185, 383-391. [CrossRef]

115. Seyyednejad, S.M.; Niknejad, M.; Yusefi, M. Study of air pollution effects on some physiology and morphology factors of Albizia lebbeck in high temperature condition in Khuzestan. Plant Sci. 2009, 4, 122-126.

116. Seyyednejad, S.M.; Niknejad, M.; Yusefi, M. The effect of air pollution on some morphological and biochemical factors of Callistemon citrinus in petrochemical zone in South of Iran. Asian J. Plant Sci. 2009, 8, 562-565. [CrossRef]

117. Chauhan, S.V.S.; Chaurasia, L.; Rana, A. Impact of air pollution on floral morphology of Cassia siamea Lamk. J. Environ. Biol. 2004, 25, 291-297.

118. Woo, S.Y.; Lee, D.K.; Lee, Y.K. Net photosynthetic rate, ascorbate peroxidase and glutathione reductase activities of Erythrina orientalis in polluted and non-polluted areas. Photosynthetica 2007, 45, 293-295. [CrossRef]

119. Agbaire, P.O.; Esiefarienrhe, E. Air pollution tolerance indices (APTI) of some plants around Otorogun gas plant in Delta state, Nigeria. J. Appl. Sci. Environ. Manag. 2009, 13, 11-14. [CrossRef]

120. Joshi, P.; Swami, A. Air pollution induced changes in the photosynthetic pigments of selected plant species. J. Environ. Biol. 2009, 30, 295-298.

121. Honour, S.L.; Bell, J.N.B.; Ashenden, T.W.; Cape, J.N.; Power, S.A. Responses of herbaceous plants to urban air pollution: Effects on growth, phenology and leaf surface characteristics. Environ. Pollut. 2009, 157, 1279-1286. [CrossRef]

122. Joshi, P.C.; Abhishek, S. Physiological responses of some tree species under roadside automobile pollution stress around city of Haridwar, India. Environmentalist 2007, 27, 365-374. [CrossRef]

123. Tripathi, A.; Gautam, M. Biochemical parameters of plants as indicators of air pollution. J. Environ. Biol. 2007, 28, 127-132.

124. Tiwari, S.; Agrawal, M.; Marshall, F.M. Evaluation of ambient air pollution impact on carrot plants at a suburban site using open top chambers. Environ. Monitor. Assess. 2006, 119, 15-30. [CrossRef]

125. Joshi, N.; Chauhan, A.; Joshi, P.C. Impact of industrial air pollutants on some biochemical parameters and yield in wheat and mustard plants. Environmentalist 2009, 29, 398-404. [CrossRef]

126. Wang, F.; Zeng, B.; Sun, Z.; Zhu, C. Relationship between proline and $\mathrm{Hg}^{2+}$-induced oxidative stress in a tolerant rice mutant. Arch. Environ. Contam. Toxicol. 2009, 56, 723-731. [CrossRef]

127. Tankha, K.; Gupta, R.K. Effect of Water deficit and $\mathrm{SO}_{2}$ on total soluble protein, nitrate reductase activity and free proline content in sun flower leaf. Biol. Planta 1992, 34, 305-310. [CrossRef]

128. Parish, S.B. The effect of cement dust on citrus trees. Plant World 1910, 13, 288-291.

129. Chaurasia, S.; Karwariya, A.; Gupta, A.D. Impact of cement industry pollution on morphological attributes of wheat (Triticum Species) Kodinar Gujarat, India. J. Environ. Sci. Toxicol. Food Technol. 2014, 8, 84-89. [CrossRef]

130. Lötschert, W.; Köhm, H.-J. Characteristics of tree bark as an indicator in high immission areas. II. Contents of heavy metals. Oecologia 1978, 37, 121-132. [CrossRef]

131. Sauter, J.J.; Kammerbauer, H.; Pambor, L.; Hock, B. Evidence for the accelerated micromor-phological degradation of epistomatal waxes in Norway spruce by motor vehicle emissions. Eur. J. For. Pathol. 1987, 17, 444-448. [CrossRef]

132. Ashmore, M.R.; Bell, J.N.B.; Mimmack, A. Crop growth along a gradient of ambient air pollution. Environ. Pollut. 1988, 52, 99-121. [CrossRef]

133. Prażak, R.; Święciło, A.; Krzepiłko, A.; Michałek, S.; Arczewska, M. Impact of Ag Nanoparticles on Seed Germination and Seedling Growth of Green Beans in Normal and Chill Temperatures. Agriculture 2020, 10, 312. [CrossRef]

134. Hatami, M.; Ghorbanpour, M.; Salehiarjomand, $\mathrm{H}$. Nano-anatase $\mathrm{TiO}_{2}$ modulates the germination behavior and seedling vigority of some commercially important medicinal and aromatic plants. J. Environ. Biol. 2014, 8, 53-59.

135. Prasad, T.N.V.K.V.; Sudhakar, P.; Sreenivasulu, Y.; Latha, P.; Munaswamy, V.; Reddy, K.R.; Sreeprasad, T.S.; Sajanlal, P.R.; Pradeep, T. Effect of nanoscale zinc oxide particles on the germination, growth and yield of peanut. J. Plant. Nutr. 2012, 35, 905-927. [CrossRef]

136. Lin, D.; Xing, B. Root uptake and phytotoxicity of ZnO nanoparticles. Environ. Sci. Technol. 2008, 42, 5580-5585. [CrossRef]

137. García-López, I.J.; Lira-Saldivar, R.H.; Zavala-García, F.; Olivares-Sáenz, E.; Niño-Medina, G.; Angélica Ruiz-Torres, N.; Méndez-Argüello, B.; Díaz-Barriga, E. Effects of zinc oxide nanoparticles on growth and antioxidant enzymes of Capsicum chinense. Toxicol. Environ. Chem. 2018, 100, 560-572. [CrossRef]

138. Zhang, Y.; Chen, Y.; Westerhoff, P.; Hristovski, K.; Crittenden, J.C. Stability of commercial metal oxide nanoparticles in water. Water Res. 2008, 42, 2204-2212. [CrossRef] [PubMed]

139. López-Moreno, M.L.; de la Rosa, G.; Hernández-Viezcas, J.A.; Peralta-Videa, J.R.; Gardea-Torresdey, J.L. X-ray absorption spectroscopy (XAS) corroboration of the uptake and storage of $\mathrm{CeO}_{2}$ nanoparticles and assessment of their differential toxicity in four edible plant species. J. Agric. Food Chem. 2010, 58, 3689-3693. [CrossRef]

140. Razzaq, A.; Ammara, R.; Jhanzab, H.M.; Mahmood, T.; Hafeez, A.; Hussain, S. A novel nanomaterial to enhance growth and yield of wheat. J. Nanosci. Technol. 2016, 2, 55-58.

141. Bayramzadeh, V.; Ghadiri, M.; Davoodi, M.H. Effects of silver nanoparticle exposure on germination and early growth of Pinus sylvestris and Alnus subcordata. Sains Malays. 2019, 48, 937-944. [CrossRef]

142. Buzea, C.; Pacheco, I.I.; Robbie, K. Nanomaterials and nanoparticles: Sources and toxicity. Biointerphases 2007, 2, 17-71. [CrossRef]

143. Jacob, J.; Swanson, R.F.; Adam, M.B.; David, B.K. Fuel Sulfur and Iron Additives Contribute to the Formation of Carbon Nanotube-like Structures in an Internal Combustion Engine. Environ. Sci. Technol. Lett. 2016, 3, 364-368. 
144. Stampoulis, D.; Sinha, S.K.; White, J.C. Assay-dependent phytotoxicity of nanoparticles to plants. Environ. Sci. Technol. 2009, 43, 9473-9479. [CrossRef]

145. Mondal, A.; Basu, R.; Das, S.; Nandy, P. Beneficial role of carbon nanotubes on mustard plant growth: An agricultural prospect. J. Nanopart. Res. 2011, 13, 4519-4528. [CrossRef]

146. Chichiriccò, G.; Poma, A. Penetration and Toxicity of Nanomaterials in Higher Plants. Nanomaterials 2015, 5, 851-873. [CrossRef]

147. Lin, C.; Fugetsu, B.; Su, Y.; Watari, F. Studies on toxicity of multi-walled carbon nanotubes on Arabidopsis T87 suspension cells. J. Hazard. Mater. 2009, 170, 578-583. [CrossRef]

148. Chun, S.; Muthu, M.; Gopal, J. Nanotoxic impacts on staple food crops: There's plenty of room for the unpredictable. Crit. Rev. Food Sci. Nutr. 2020, 60, 3725-3736. [CrossRef]

149. Wild, E.; Jones, K.C. Novel method for the direct visualization of in vivo nanomaterials and chemical interactions in plants. Environ. Sci. Technol. 2009, 43, 290-294. [CrossRef] [PubMed]

150. Lin, S.; Reppert, J.; Hu, Q.; Hudson, J.S.; Reid, M.L.; Ratnikova, T.A.; Rao, A.M.; Luo, H.; Ke, P.C. Uptake, translocation, and transmission of carbon nanomaterials in rice plants. Small 2009, 5, 1128-1132. [CrossRef] [PubMed]

151. Lin, D.; Xing, B. Phytotoxicity of nanoparticles: Inhibition of seed germination and root growth. Environ. Pollut. 2007, 150, 243-250. [CrossRef] 